\title{
HIV-1 replication changes the function of the PKR activator PACT
}

\author{
Guerline Clerzius ${ }^{1,2}$, Eileen Shaw ${ }^{1,2}$, Aïcha Daher ${ }^{1}$, Samantha Burugu ${ }^{1,3}$, Jean-François Gélinas ${ }^{1,3}$, Jean-Pierre Routy ${ }^{2,4}$ \\ , Rekha C Patel ${ }^{5}$, Anne Gatignol ${ }^{1,2^{*}}$ \\ From Frontiers of Retrovirology: Complex retroviruses, retroelements and their hosts \\ Cambridge, UK. 16-18 September 2013
}

\section{Background}

HIV-1 translation is modulated by the activation of the interferon-inducible Protein Kinase R (PKR), which phosphorylates its downstream target, the eukaryotic translation Initiation Factor 2 (eIF2a). Phosphorylated eIF2a blocks translation initiation and consequently viral replication. PKR is not activated in HIV-1-replicating lymphocytes. Inactivated PKR allows high HIV-1 translation and may contribute to HIV-1 persistence in several cell types.

\section{Methods}

Peripheral blood mononuclear cells (PBMCs) were infected with HIV-1 molecular clone pNL4-3. Viral kinetics were followed by reverse transcriptase (RT) assay. Expression of viral and cellular proteins were monitored by immunoprecipitation (IP) and western blots.

\section{Results}

PKR is transiently induced and activated in PBMCs after HIV-1 infection and dephosphorylated during viral replication. The expression of two double-stranded RNA binding proteins, the RNA adenosine deaminase (ADAR) 1 and the PKR Activator (PACT) is induced during HIV-1 infection. By co-IP of HIV-1-infected lymphocytes with antibodies against PKR, we identified a multiprotein complex, which contains ADAR1 and PACT. PACT is known to activate PKR after a cellular stress. In cells transfected with an HIV-1 molecular clone, PACT unexpectedly inhibited PKR and eIF2a phosphorylation and increased HIV-1 protein expression

"Virus-Cell Interactions Laboratory, Lady Davis Institute for Medical Research" Montréal, QC, Canada

Full list of author information is available at the end of the article and virion production. Short hairpin RNAs against PACT decreased HIV-1 protein expression. Furthermore, ADAR1, the TAR RNA binding protein, TRBP, and PACT all inhibit PKR and eIF2a phosphorylation in HIV-1-expressing cells. In the astrocytic cell line U251MG that weakly expresses TRBP, PACT also mediated an increased HIV-1 protein expression and a decreased PKR phosphorylation. Finally, PACT and ADAR1 interact with each other in the absence of RNA, which may mediate the change of PACT function in HIV-1 infected cells.

\section{Conclusions}

In contrast to its previously described activity, PACT contributes to PKR dephosphorylation during HIV-1 replication. This activity is in addition to the previously described inhibition of PACT by TRBP [1] and to the direct activity of ADAR1 on PKR [2]. The change in PACT function is likely due to its interaction with ADAR1 but does not exclude the contribution of another HIV-1 component or virally-induced cellular factor. PKR inactivation likely contributes to HIV-1 persistence in several cell types.

\section{Acknowledgements}

This work was supported by grants from the Canadian Institutes for Health Research and by the Réseau-SIDA Maladies Infectieuses from the Fond de la Recherche du Québec en Santé.

\section{Authors' details}

"Virus-Cell Interactions Laboratory, Lady Davis Institute for Medical Research," Montréal, QC, Canada. ${ }^{2}$ Department of Medicine, Division of Experimental Medicine, McGill University, Montréal, QC, Canada. ${ }^{3}$ Department of Microbiology and Immunology, McGill University, Montréal, QC, Canada. ${ }^{4}$ Chronic Viral IIIness Service and Division of Hematology, McGill University Health Centre, Montréal, QC, Canada. ${ }^{5}$ Department of Biological Sciences, University of South Carolina, Columbia, SC, USA.

Published: 19 September 2013 


\section{References}

1. Daher A, Laraki G, Singh M, Melendez-Peña CE, Bannwarth S, Peters AH, Meurs EF, Braun RE, Patel RC, Gatignol A: TRBP control of PACT-induced phosphorylation of PKR is reversed by stress. Mol Cell Biol 2009, 29:254-265.

2. Clerzius G, Gélinas JF, Daher A, Bonnet M, Meurs EF, Gatignol A: ADAR1 interacts with PKR during human immunodeficiency virus infection of lymphocytes and contributes to viral replication. J Virol 2009,

83:10119-10128.

doi:10.1186/1742-4690-10-S1-P35

Cite this article as: Clerzius et al.: HIV-1 replication changes the function of the PKR activator PACT. Retrovirology 2013 10(Suppl 1):P35.

Submit your next manuscript to BioMed Central and take full advantage of:

- Convenient online submission

- Thorough peer review

- No space constraints or color figure charges

- Immediate publication on acceptance

- Inclusion in PubMed, CAS, Scopus and Google Scholar

- Research which is freely available for redistribution

Submit your manuscript at www.biomedcentral.com/submit
C Biomed Central 